AperTO - Archivio Istituzionale Open Access dell'Università di Torino

\title{
Authoritarian resilience through top-down transformation: making sense of Myanmar's incomplete transition
}

\section{This is the author's manuscript}

Original Citation:

Availability:

This version is available http://hdl.handle.net/2318/1710887

since 2019-08-30T17:54:38Z

Published version:

DOI:10.1017/ipo.2019.8

Terms of use:

Open Access

Anyone can freely access the full text of works made available as "Open Access". Works made available under a Creative Commons license can be used according to the terms and conditions of said license. Use of all other works requires consent of the right holder (author or publisher) if not exempted from copyright protection by the applicable law. 


\section{IIIS AperTO}

UNIVERSITÀ

DEGLI STUDI

DI TORINO

This is the author's postprint version of the contribution published as:

Ruzza, S., Gabusi, G., \& Pellegrino, D. (2019). Authoritarian resilience through top-down transformation: Making sense of Myanmar's incomplete transition. Italian Political Science Review/Rivista Italiana Di Scienza Politica, 49(2), 193-209. doi:10.1017/ipo.2019.8

The publisher's version is available at:

https://www.cambridge.org/core/journals/italian-political-science-review-rivistaitaliana-di-scienza-politica/article/authoritarian-resilience-through-topdowntransformation-making-sense-of-myanmars-incompletetransition/C6913E4E9456EBF6F9D110CF752FD9C8\#

When citing, please refer to the published version. 


\title{
Authoritarian resilience through top-down transformation: making
}

\author{
sense of Myanmar's incomplete transition
}

\author{
Stefano Ruzza (corresponding author), Università degli Studi di Torino \\ stefano.ruzza@unito.it
}

Giuseppe Gabusi, Università degli Studi di Torino

Davide Pellegrino, Università degli Studi di Torino

\begin{abstract}
:
Starting from the imperfect nature of Myanmar's democracy, this article aims to answer two questions. First, can Myanmar's transition be defined as a case of democratization, or is it, rather, a case of authoritarian resilience? To state this differently: is the progress enjoyed by Myanmar's polity the outcome of an ongoing process that is supposed to lead to a fully fledged democracy, or, rather, an attempt to enshrine elements of authoritarian governance under a democratic guise? Second, if the balance leans towards the latter instead of the former, how did authoritarian resilience work in Myanmar? The transition is analysed from a long-term perspective, moving from the 1988 pro-democracy uprising up to the most recent events. Data were collected from available published sources and from three fieldworks conducted by the authors in Myanmar. The article concludes that Myanmar's transition is better understood as a case of authoritarian resilience than as democratization and highlights three core traits of Myanmar's authoritarian resilience: first, the very top-down nature of the political transformation; second, the incumbents' ability to set the pace of political reform through the


use of repression and political engineering; and third, the divide-and-rule strategy used as a means to keep contestations separated and parochial.

[SPECIAL ISSUE]

Keywords: Myanmar, authoritarian resilience, democratization, liberalization, transformation, military regime, democracy

\section{Introduction: is Myanmar a case of democratization?}

The landslide victory achieved by the National League for Democracy (NLD) in the general elections of $8^{\text {th }}$ November 2015 and the subsequent stepping into office of Aung San Suu Kyi, long-time political challenger of the junta, are considered landmarks in Myanmar's ongoing democratization. But can post-2015 Myanmar be defined as a democracy? As a matter of fact, the 2008 constitution, on which the 2015 elections rested, has several safeguards aimed at protracting the power of the country's former ruling elite, Myanmar's armed forces, also known as the Tatmadaw. Most notably, it automatically assigns three core ministries (Defence, Home, Borders) to the military, assigns 25\% of parliamentary seats to uniformed MPs, provides budgetary and judiciary independence to the armed forces, and sets up a failsafe mechanism that gives power back to the Tatmadaw in case of a national emergency. The constitution can be amended only with a majority of $75 \%$ plus one of the votes, hence the consent of the uniformed MPs being required for any change to take place. These are not the only signs of persisting praetorianism (Huntington 1968) in Myanmar as the Tatmadaw still occupies a prominent role in the country, from the management of resources through military-controlled economic conglomerates to informal governance exercised at both the 
national and local levels. The behaviour of Myanmar's military elite regarding the electoral results in 2015, when compared with 1990 , can be seen as telling in relation to the persistent power of the military as well. In both cases, the political party contiguous to the junta suffered an astounding defeat. Yet in 1990 the military decided to turn the tables and reject the results, while in 2015 the Tatmadaw accepted them. What is the reason for this radically different behaviour? While it may be explained by the inability or unwillingness of the Tatmadaw to contest the results, it may also indicate that whatever comes out of the ballot is no longer a concern for the military's interests.

The persistence of authoritarian rule in Myanmar's polity points to the notion of authoritarian resilience; that is, the ability of an authoritarian regime to adapt to liberalizing shocks without having to suffer an authoritarian breakdown. It was first introduced by Nathan in 2003 to account for the lack of Chinese democratization, and it has been applied since to a variety of cases, from Arab countries to Cuba (Heydemann and Leenders 2011; Hess 2013; Whitehead 2016). However, the question of whether and how authoritarian resilience has constrained and limited Myanmar's democratization has not been addressed yet. Taking the imperfect democratic nature of Myanmar's current regime as a point of departure, this article aims to fill this gap by answering two questions. First, can Myanmar's transition be defined as a case of democratization, or is it, rather, a case of authoritarian resilience? To state this differently: is the progress enjoyed by Myanmar's polity the outcome of an ongoing process that is supposed to lead to a fully fledged democracy, or, rather, an attempt to enshrine elements of authoritarian governance under a democratic guise? Second, if the balance leans towards the latter instead of the former, how did authoritarian resilience work in Myanmar, and how has it avoided a turn towards fully fledged democratization? Are there any significant peculiarities

\section{iris-AperTO}


of Myanmar's authoritarian resilience in comparison with other cases already covered in the literature?

Myanmar's regime transition is analysed from a long-term perspective, from the 1988 prodemocracy uprising to 2017. Data were collected from available published sources and from three fieldworks conducted by the authors in Myanmar (May 2014, May 2016 and May 2018, covering Yangon, Naypyidaw, Kengtung, Mong La and Myitkyina), employing semi-structured interviews with representatives of political parties, state institutions and civil society organizations. Other visits to the country, as well as informal conversations with researchers, journalists, expats and various stakeholders interested in Myanmar, both within and outside the country, also inform this article.

The article is structured as follows. The next section elaborates on the notion of authoritarian resilience. Section three employs indices commonly used to measure the quality of democracy (Freedom House rating, Polity IV, Varieties of Democracy) to track changes in the quality of Myanmar's regime. The fourth section analyses Myanmar's 'long and slow' regime transition, subdividing it into five phases and recalling significant major events. Sections five and six elaborate on the data provided in the previous section, each respectively addressing one of the two guiding questions. Section five frames the transition as a case of authoritarian resilience rather than democratization, while section six highlights the core traits of Myanmar's authoritarian resilience, putting it side by side with other cases covered in the literature. The conclusions summarizes the main findings, stressing that while Myanmar's transition may appear as a case of incremental democratization, it is better understood as a case of authoritarian resilience which generated a hybrid regime.

A note on nomenclature: from independence to 1989 , the official name of the country was Burma, while in 1989 the government renamed the country Myanmar. In this article, Burma is 
used only with regard to pre-1989 Myanmar, while the current official name is adopted in all other instances.

\section{Authoritarian resilience}

A general definition of authoritarian resilience is not available in the literature, as the focus is, rather, on case studies. Nathan (2003) has analysed how the Chinese ruling elite has managed to transition the country from totalitarianism to authoritarianism, abandoning a utopian/charismatic style of governance while embracing technocracy and reducing control over private speech and action. The change was triggered by the need to adapt to the demands of economic globalization, although the Chinese Communist Party (CCP) did not want to relinquish power and wished to keep the regime stable. Nathan concluded that, in contrast to the expectations derived from Talcott Parsons' theory, the liberalizing changes introduced by the CCP have not led to regime change, and that even if "such a transition might still lie somewhere in the future, the experience of the past two decades suggests that it is not inevitable" (Nathan 2003: 16). Fifteen years later, Nathan's argument still holds true and other authors have elaborated further from his premises (Stockmann and Gallagher 2011; Chung 2017).

Heydemann and Leenders (2011) applied the notion of authoritarian resilience to the 2011 Arab Revolts to account for the lack of regime change in the majority of the countries hit by the protests. They argued that two processes have developed in parallel and interacted with each other: on the one hand, the classic democratic contagion effect (Huntington 1991), where protests in one country gain momentum thanks to what is going on in neighbouring states; and on the other, social learning on the side of the regimes, which have adapted their "repertoires of suppression" according to the developments on the ground in their own 
country as well as in neighbouring countries, and engaged proactively in order to avoid international intervention as well as defections from their own security apparatus. As the incumbents have outpaced protestors in terms of social adaptation in Algeria, Morocco, Jordan, Saudi Arabia, Yemen and Syria, they have managed to stall democratization and protect authoritarian rule. Other authors have engaged with authoritarian resilience in Arab countries, especially after the 2011 Revolts (Lynch 2011; Bellin 2012; Yom and Gause 2012), further expanding Heydemann and Leenders' argument.

Interestingly, Hess (2013) merged Arab countries and China in a single analysis, trying to account for the authoritarian vulnerability of the two countries where the 2011 Arab Revolts succeeded - Tunisia and Egypt - vis-à-vis the resilience of autocracy in China. He pointed out four main drivers of protest that can act as authoritarian vulnerabilities: economic performance, unemployment, inequality and corruption. While Tunisia and Egypt fared badly in all four dimensions, only inequality and corruption have been a concern for China. Hess then recalled the classical model of authoritarian capacity (Way 2008) breaking it down to its three primary elements: coercive capacity, political capacity and discretionary control over the economy. On these points, Tunisia and Egypt performed as well as China. Hence, to account for the very different political trajectory followed by the two North African countries in comparison with China, Hess introduced what he defined as "two missing variables" centralization and modes of contention - arguing that decentralization manages to keep protest 'parochial' (i.e., local) and prevents it from escalating to the national scale, thus providing an essential layer of authoritarian protection. According to Hess's argument, it is decentralization that has managed to protect Chinese authoritarianism, while its absence led to regime collapse in both Egypt and Tunisia.

\section{iris-AperTO}




\section{Not an autocracy or a democracy: Myanmar as a hybrid regime}

Today, Myanmar's polity enjoys a higher degree of civil and political freedoms than in the past, as registered by all the indices commonly used to measure the quality of democracy: Freedom House rating (FH), Polity IV (PIV), and Varieties of Democracy (V-Dem). Figure 1 shows the trends of the FH, PIV and V-Dem indices related to Myanmar for the years 19882017.

The Freedom House rating scale ranges from 7 (least free) to 1 (most free) and takes into account both political rights and civil liberties. It can be considered a comprehensive indicator of how much a regime conforms to the ideal of a liberal democracy. The Polity IV range goes from -10 (closed autocracy) to +10 (consolidated democracy), considering political participation, checks on executive authority as well as openness and competitiveness of executive recruitment. PIV reflects a narrower definition of democracy than FH. The Varieties

of Democracy (V-Dem) Electoral Democracy Index ranges from 0 (lowest democratic achievement) to 1 (highest democratic achievement) and rests on Dahl's notion of polyarchy.

\section{[INSERT FIGURE 1 APPROX HERE]}

The data summarized in figure 1 allow two conclusions to be drawn. First, there has been a trend of sustained and relatively fast-paced improvement of democracy in Myanmar, starting in 2010. Second, the quality of democracy in post-2016 Myanmar is debatable. On the one hand, the narrow PIV already defines Myanmar as a democracy. On the other hand, both a comprehensive index (the FH) and a more focused one (the V-Dem) are more cautious. Myanmar today can be defined not as a full democracy (or at least not yet) but rather as a hybrid regime (Diamond 2002; Levitsky and Way 2010) where competitive multi-party elections coexist with authoritarian elements. Hybrid regimes are notoriously hard to define (Cassani 2014) but the notion of electoral authoritarianism (Levitsky and Way 2002; Way

\section{iris-AperTO}


2004; Schedler 2002 and 2006; Wigell 2008; Bogaards 2009) has been widely used to describe the nature of Myanmar's regime since 2010 (Macdonald 2013; Jones 2014; Morgenbesser 2015), and even after the 2015 elections (Lee Huang 2017), although its use sparked some debate (Farrelly 2015). The quality of the regime in post-2015 Myanmar is perhaps best captured by the concept of competitive authoritarianism, where a regime is one "in which elections are the primary means of gaining and keeping power" and where "regular abuses of civil and political liberties by incumbent political leaders make it impossible to call these regimes democratic" (Way 2004: 147).

Although all the democracy indices started moving upwards in 2010, the roots of Myanmar's transition are to be found in earlier years. It should suffice to say that the 1990 elections were not voided altogether, but declared by Than Shwe, leader of the ruling junta, as meant to establish a constituent assembly instead of forming a parliament. The constituent assembly was convened in 1993, and although it was suspended in 1996, it restarted its operations in 2004, which in turn led to the 2008 constitution and the 2010 and 2015 elections (Ruzza and Gabusi 2018). A focus on the more recent events in Myanmar's political history alone would fail to reveal the how and why of Myanmar's transition and of its authoritarian resilience.

\section{Myanmar's 'slow and long' transition}

Myanmar's transition is divided into five phases in order to make the information manageable. The first phase (1988-1996) started with the uprisings of 1988 that made Aung San Suu Kyi and the NLD the most prominent challengers of the junta and ended with the indefinite-term adjournment of the constituent assembly in 1996. This phase can be defined as a failed democratization (Huntington 1991; Diamond 2000; Levitsky and Way 2015; Cassani and Tomini 2018), as grass-roots demands for democracy were stopped. In the

\section{iris-AperTO}


second phase (1996-2003), the regime improved its domestic position, while the reconfiguration of Myanmar's international relations put pressure on the junta for some measure of political liberalization. The third phase (2003-2010) began with the plan of reforms launched by then prime minister Khin Nyunt and concluded short of the 2010 elections. It is during this phase that liberalization took place, although its effects were not visible at the time. The fourth phase (2010-2015) started with the 2010 elections and ended short of the 2015 elections. During phase four, Myanmar's regime assumed the traits of electoral authoritarianism, with the instalment of a 'civilianized' cabinet mostly comprised of ex-military personnel affiliated with the Union Solidarity and Development Party (USDP) and led by former general Thein Sein. The fifth phase (2015 onwards) was coincident with the first part of the Aung San Suu Kyi administration. The Tatmadaw-affiliated USDP accepted electoral defeat and a new elite rose to power, yet the power of the military remained unscathed and free from civilian control. This allows Myanmar's regime in this last phase to be defined as competitive authoritarianism.

\section{Failed democratization (1988-1996)}

Burma was ruled by a military regime since Ne Win's coup in 1962 . The junta applied its 'Burmese way to socialism', making nationalization and state control of the economy the norm. Development never took off, and two rounds of demonetization in 1985 and 1987, intended to restrict the money supply and tame inflation, generated massive economic damage. As people were deprived of their savings, inflation resurged, and the economy descended into chaos. The diffusion of barter and smuggling also strengthened insurgents in Burma's peripheral areas (Myat Thein 2004).

\section{iris-AperTO}


From March to August 1988, out of people's discontent, protests in the country gained momentum, finally exploding in nationwide riots on $8^{\text {th }}$ August: the so-called '8-8-88 uprising' (Kyaw Yin Hlaing 2013). It was at this moment that Aung San Suu Kyi arrived centre stage. The daughter of general Aung San (the architect of Burma's independence), she had come to Yangon to take care of her old and ill mother. Because of her political ancestry, she was asked by the protest leaders to lead the anti-government movement. In a rally held on $26^{\text {th }}$ August at the Shwedagon Pagoda, she addressed a crowd of at least 500,000 people, advocating for the dismantlement of the one-party system and calling for "free and fair elections to be arranged as quickly as possible". In September the National League of Democracy was founded (Kipgen 2016: 87-91).

In the face of mounting protests, Ne Win resigned in July and multi-party elections were promised, but as this proved insufficient to stop the protests the Tatmadaw brutally stepped in (Charney 2009; Holliday 2010). The constitution was suspended, martial law was introduced and a new military regime led by General Saw Maung was instated. Forceful repression caused the death of thousands of civilians, as well as mass incarceration of protesters and of political enemies, bringing the uprisings to a brutal halt. Since students were among the most politically active segment of society during the riots, universities were closed all around the country (Kipgen 2016: 63-65).

The promised elections were held in May 1990. To the surprise of the Tatmadaw, the NLD obtained a landslide victory, taking 392 of the 485 available seats, with $58.7 \%$ of the votes. The National Unity Party (NUP), a political expression of the military, won only $21.2 \%$ of the votes and 10 seats, due to the first-past-the-post electoral system (Kipgen 2016: 125-134). Unwilling to accept such a crushing defeat, the junta declared that the vote was not meant to gather a new parliament but rather to create a constitutional assembly named the National

\section{iris-AperTO}


Convention. In April 1992, general Than Shwe replaced Saw Maung in a palace coup. In order to subtract space to grass-roots civil society organizations and to generate support for government policies, the drafting of a new constitution included, the junta established the Union Solidarity and Development Association (USDA) in 1993, the same year in which the National Convention began its activities. The National Convention was mostly controlled by the incumbents, since the majority of its members were township-level officials selected by the junta, while very few of its members were elected. Over time, all but the military delegates abandoned the National Convention, with the NLD representatives leaving it in 1995 . The Convention was then adjourned indefinitely in 1996, but not disbanded. And even though the National Convention failed to deliver a constitution, several of the principles and norms present in the 2008 constitution were actually drafted during this period (Kipgen 2016: 122126).

Away from Yangon, significant developments were happening in Myanmar's borderlands as well. Since independence, the country has been plagued by a number of insurgencies affecting border regions. Between 1989 and 1994, the junta managed to secure informal ceasefires with a number of ethnic armed organizations (EAOs). The opportunity was provided by the collapse of the Communist Party of Burma (CPB), an ideological insurgency mostly active in the Eastern part of Myanmar (Shan State), which was replaced by a number of smaller ethnoidentitarian insurgencies. In order to avoid cooperation between old and new insurgent groups, as well as between democratic protesters and insurgents, the commander of Military Intelligence at the time, General Khin Nyunt, agreed informal ceasefires with some EAOs. This allowed the Tatmadaw and the junta to concentrate their strength against a smaller number of divided enemies (as military means were concentrated against non-ceasefire EAOs), as well

\section{iris-AperTO}


as to spare resources to keep the democratic threat in check (Zaw Oo and Win Min 2007; Ruzza 2015).

The junta strengthens its position (1996-2003)

During this phase the junta kept on repressing political activity and occupying civil society space through its USDA arm. It also continued on its counter-insurgency campaign, achieving major victories, especially against the Karen insurgency in the south-eastern part of Myanmar (South 2008; Ruzza 2015). The military tightened its grip on Myanmar's economy as well, by establishing two huge conglomerates: the Union of Myanmar Economic Holdings (UMEHL, founded in 1990) and the Myanmar Economic Corporation (MEC, founded in 1997). They are both still under the control of the Tatmadaw and have generated additional income for the military and their families (ICG 2012). It must also be noted that the distinction in contemporary Myanmar between the military and the state gets blurred in state-owned enterprises (SOEs) engaged in the most lucrative economic sectors, like the mining of precious stones and minerals, oil and gas, and construction (Rieffel 2015). Most of these commodities are to be found in border areas, where contestation by EAOs provides the Tatmadaw with a narrative allowing for intervention, and consequently a freedom of action unthinkable in a normal situation.

The West was trying to pressure Myanmar through the use of sanctions. The European Union added further sanctions to its arms embargo, in force since 1990, while the United States and Canada prohibited new investments in Myanmar as well as any related transactions in 1997. However, this did not harm the regime much, as it could rely on a regional ally playing the role of democratic 'black knight' - that is to say, a power "whose economic, military, and/or diplomatic support helps blunt the impact of US or EU democratizing pressure" (Levitsky and

\section{iris-AperTO}


Way 2010: 41; see also Hufbauer, Schott, and Elliott 2007). This was China, which became the country's largest economic partner and foreign investor: between 1988 and 2003, Myanmar's exports to China grew by 1.3 times, but its imports increased by more than seven times (Alamgir 2008: 989), and "from 1988 to 2010, China's cumulative investment reached 9.6 billion USD [...], a third of which went into oil, natural gas and hydropower projects" (Ramachandran 2016: 11). According to the Stockholm International Peace Research Institute (SIPRI) database, between 1988 and 2010 China topped the list of arms suppliers to Myanmar, and in 1989 Myanmar signed a US\$1 billion deal with Beijing - "the largest arms purchase agreement in Myanmar's history" - for the purchase of military equipment, followed in 1994 by another US $\$ 400$ million contract. China also helped to set up Myanmar's defence industries (Ramachandran 2012: 7).

In 1997, Myanmar joined ASEAN, an event that provided a push in favour of political reforms. ASEAN member states advocated for a softening of the Myanmar regime, but unlike Western pressure, their pleas had some effect as they were attached to economic incentives in the form of international trade. In fact, at the time of accession, the ASEAN market "accounted for 42 and 40 percent of Myanmar's exports and imports respectively" (Cribb 1998: 56). Furthermore, according to an insider's view, Myanmar's membership of ASEAN exposed the junta to the outside world and made it realize how poorly the country had managed through the years of military rule in comparison to the least-developed ASEAN members. This made obvious to the military rulers the necessity of some political transformation as a means for economic development.

Autocrats become reformers (2003-2010)

\section{iris-AperTO}


The West kept its policy on Myanmar steady. In July 2003, Washington introduced new sanctions, banning the import of any article produced in Myanmar and expressly targeting the two conglomerates linked to the military; these sanctions would be replicated by the European Union in 2004 and 2006. These were also the years of the US neoconservative ideology and of the notion of regime change through military intervention. The fear of an attack on Yangon from the sea is one of the reasons why the regime moved the capital to the centre of the country in 2010, where a monumental new city was built from scratch and aptly named Naypyidaw, 'the seat of the king' (Farrelly 2018).

While Myanmar suffered international isolation, the Chinese presence kept on growing. In June 2000, China and Myanmar signed a 'Joint Statement on the Framework of Future Bilateral Relations and Cooperation', which was followed by a visit to Myanmar by President Jiang Zemin. This led to more than thirty technical agreements being signed between 2004 and 2006. Out of the twenty largest manufacturing projects contracted by China with Myanmar from 2000 to 2010, thirteen were contracted in the years 2000-2003. Large investments in the oil and gas, hydropower and mining sectors took place, while China's total trade with Myanmar jumped from US\$508.03 billion in 1999 to US\$1,077.24 billion in 2003, then increasing to reach US\$2,907.36 billion in 2009 (Steinberg and Hongwei 2012). The increasing Chinese influence, however, was not seen positively, also because Beijing supported some insurgencies on Myanmar's northern border. According to Lee (2012), it was the dominant Chinese influence that prompted the junta to diversify Myanmar's suppliers by opening up the country.

In August 2003, after several Tatmadaw purges, Khin Nyunt became Myanmar's prime minister. A few days after entering office, he announced the 'Seven-step Roadmap to a discipline-flourishing democracy'. The Roadmap starts with the reconvening of the National 
Convention and moves through the adoption of a new constitution to reach "free and fair elections" and the "building of [a] modern, developed and democratic state" (Khin Maung Win 2004). The roadmap did not indicate deadlines; it just outlined which steps the junta may have been willing to undertake under its own conditions and at a time of its choosing.

The actual adoption of the roadmap was influenced by intra-ASEAN relations. The policy of forward engagement adopted by the Thai government generated stronger economic interaction between Thailand and Myanmar. Thailand's border trade with Myanmar grew at an average annual rate of 24.5\% between 1994 and 2001 (Mya Than 2005: 47). As economic interdependence grew, ASEAN took the opportunity to send a signal to the junta in 2003, asking for a change in Myanmar's domestic situation by convening the 'Forum on International Support for National Reconciliation in Myanmar', also known as the 'Bangkok Process' (Bellamy and Drummond 2012: 248-49). In December 2003, Khin Nyunt took part in it, and Thaksin Shinawatra, prime minister of Thailand, suggested he engage with the opposition. It is likely that economic incentives played a large role in influencing Myanmar's political stance, as in May 2004 the first step of the Roadmap was put into practice with the reconvening of the National Convention.

The junta leader, Than Shwe, accepted the idea of relaunching the National Convention, as he fathered it in 1993. Furthermore, at this point in time the junta felt reassured of its ability to contain and crush demands for secession, autonomy and democracy (Jones 2014). Than Shwe, however, did not trust Khin Nyunt enough to leave him in control of the process. A purge ensued in 2004, Khin Nyunt was arrested and General Thein Sein, Than Shwe's most trusted man, was then appointed to lead the constitutional process. Since the NLD was still disgruntled by its previous experience with the National Convention it decided not to rejoin it. A facade of pluralism was obtained by inviting delegates from ceasefire EAOs, although their

\section{iris-AperTO}


requests to introduce federalism to the constitution were disregarded. The Saffron Revolution of 2007, during which thousands of Buddhist monks supported popular protests, did not manage to disrupt the Roadmap. Rather, it confirmed to the junta the need for reforms. Protests were violently repressed but with limited bloodshed (the UN Special Rapporteur on human rights in the country, Paulo Sergio Pinheiro, reported a death toll of 30) and in May 2008 the constitution was brought into force with a referendum. The junta announced that 92.48\% of voters had approved the constitution, with a turnout of $98.12 \%$ (Kipgen 2016 : 126).

The 2010 elections and the Thein Sein government (2010-2015)

With a new constitution in force, elections were held on $7^{\text {th }}$ November 2010. The USDA was transformed into a party, the USDP, and won with a landslide $76.52 \%$, securing 883 seats out of 1,154 in the two Hluttaws (houses), on top of the $25 \%$ of seats automatically assigned to the Tatmadaw (Kipgen 2016: 135-141). The NLD boycotted the elections, demanding constitutional changes, international supervision of the vote and liberation of political prisoners, Aung San Suu Kyi included. Several ethnic parties were denied registration as well. In short, the 2010 elections were neither free nor fair, and the process remained "deeply flawed", in the words of the then United Nations human rights envoy for Myanmar (MacFarquhar 2010).

A few days after the elections, the junta set Aung San Suu Kyi free. In February 2011, the parliament convened, and the junta was dissolved and replaced with a new 'semi-civilian' government under the presidency of former general Thein Sein. Than Shwe left office, both as the junta chairman and as the commander-in-chief of the Tatmadaw, leaving this last role to General Min Aung Hlaing. The media were progressively freed and by-elections were held in

\section{iris-AperTO}


April 2012 to fill 45 vacant parliamentary seats. This time the NLD entered the fray and won 43 of the 44 seats they contested, with Aung San Suu Kyi entering parliament. This event greatly enhanced the credibility of Myanmar's ongoing transition (Olarn 2012; Egreteau 2016: 68-69), and in 2012, as the Thein Sein reformist agenda started to take shape, the West gradually started to lift sanctions. In November 2012, Barack Obama made history by being the first US president in charge to visit Myanmar.

In 2013 a Constitutional Review Committee was formed, composed of 109 members, of which only seven were affiliated with the NLD. In January 2014, the Committee submitted its report to parliament but it did not make any recommendations for change. Rather, it clearly indicated three aspects of the constitution that should not be revised: the role of the military in politics, the presidential requirement not to have a foreign spouse or children, and the process for constitutional amendments itself (Crouch and Ginsburg 2016). In February 2014, the parliament established an Implementation Committee, with the mandate of reviewing the report, but at this point the process was already delegitimized. The NLD protested, but the government sent a crystal-clear message, warning the NLD "that its rallies in support of constitutional change must not provoke social unrest, or else this may necessitate a declaration of emergency and military takeover" (Crouch and Ginsburg 2016: 68).

Two significant developments regarding the borderlands also need to be mentioned. First, in 2009 - that is to say, immediately after the new constitution came into force -conflict reescalated in Myanmar, reaching levels of violence close to those of the 1980s, before Khin Nyunt's ceasefires. The conflict was mostly concentrated in the northern areas bordering with China (Kachin and Shan states) and is still present. The reasons for this resurgence of violence can be found in the progressive disenfranchisement of the ethnic minorities from the ceasefire experience and from the process of political reform (Woods 2011; Brenner 2015

\section{iris-AperTO}


and 2017; Ruzza 2015). Second, in 2011 Thein Sein tried to deal with the state of constant strife in the borderlands by launching his own peace plan. While the more muscular counterinsurgency approach followed by the Tatmadaw was not entirely sidelined, Thein Sein opened up a season of dialogue that managed to achieve, in October 2015, the so called 'Nationwide Ceasefire Agreement' (NCA). It was not really a nationwide agreement, as it included only eight of 21 EAOs, amounting to about $20 \%$ of the total number of insurgents active in the country. Nonetheless, it was the first public and multilateral ceasefire agreement in the history of Myanmar (Ruzza and Gabusi 2018).

The 2015 elections and the Aung San Suu Kyi government (2015-)

The 2015 general elections enhanced optimism about the transition, as international observers could certify the fairness of the electoral process in an environment characterised by freedom of the media and of public debate (ANU Myanmar Research Center 2015). The NLD obtained a landslide victory: in the House of Representatives, of the contested 323 seats the NLD won 255 , obtaining $57.95 \%$ of total seats in the House, while in the House of Nationalities the NLD won 135 of the contested 168 seats, thereby obtaining $60.27 \%$ of all seats in the House (ICG 2015).

The new NLD government was then installed in March 2016. Aung San Suu Kyi, whom the 2008 constitution barred from becoming president due to her marriage to a foreigner, carved out for herself the new position of 'State Counsellor', a sort of premiership that made her the de facto leader of the country, "above the President", as per her words. She also assumed the functions of Minister of Foreign Affairs and Minister of the President's Office. The USDP and the Tatmadaw accepted the electoral outcome and Than Shwe, Thein Sein and Aung Min

\section{iris-AperTO}


Hlaing all separately visited and congratulated Aung San Suu Kyi, agreeing to support a smooth transition (Freedom House 2016).

In its 2015 electoral manifesto, the NLD indicated that constitutional reform was among its priorities, but that document does not provide any details besides listing a series of uncontroversial principles. The same document also acknowledges that "the Tatmadaw is an essential institution of the state" (NLD 2015: 7). Both President Htin Kyaw (who took office in 2016) and President Win Myint (who replaced Htin Kyaw after his resignation in 2018) referred to intended constitutional changes in their inaugural speeches, but reform has not yet taken place (Myanmar Times 2016; President's Office 2018). During a visit to Singapore in August 2018, Aung San Suu Kyi recalled that amending the constitution is one of the NLD goals and declared that "the completion of democratic transition must necessarily involve the completion of a truly democratic constitution". However, she also stated that she would work for change in cooperation with the Tatmadaw, adding that changes would be "through negotiations, always keeping in mind that national reconciliation is one of our greatest needs" (Aung San Suu Kyi 2018).

The most significant constitution-related change to date has been the creation of the position of State Counsellor. It was approved in April 2016 without the vote of the military MPs, who boycotted the session, declaring that the bill violated the constitution (Htoo Thant 2016). Besides this, the NLD-led government has not yet made any major attempts to reform civilmilitary relations, as the NLD has accepted, at least for the time being, "the current pattern of civil-military relations enshrined in the constitution" (Maung Aung Myoe 2018: 207).

The NLD government set the peace process at the top of its agenda, renaming it the ' $21^{\text {st }}$ Century Panglong Conference' (21CPC), although its architecture has remained basically unchanged. Progress has been slow, with the only achievement to date being the joining of the

\section{iris-AperTO}


NCA by two very small EAOs in February 2018. Distressing signals are emerging as well, as the largest EAO has created an alliance of non-NCA members that is asking for an alternative process. This alliance joins all the EAOs currently in a state of open belligerency with the government, as well as a few other groups holding on a bilateral ceasefire. The positions of the Tatmadaw and of the EAOs are still distant, as several EAOs are asking for reforms in advance of demobilization, while the Tatmadaw prefers the reverse, and the substantial presence of the military in the borderlands makes peace talks difficult. EAOs are also asking for constitutional changes, something that is supposed to come out of the $21 \mathrm{CPC}$. However, the Tatmadaw, which is officially a party in the process, is systematically acting to remove any controversial demand for reform from the negotiations, accepting only bland and non-binding declarations of principle (Barany 2018; Chambers and McCarthy 2018; Maung Aung Myoe 2018).

In more general terms, the Tatmadaw is retaining its position of privilege in Myanmar. Besides of its political weight, it also benefits of a very good economic position. The military budget for 2017-2018 almost exceeds "financing for health, education and welfare combined" (Chambers and McCarthy 2018: 4). On top of this, rents from the UMEHL, the MEC and various SOEs, as well as from informal borderland extraction, keep on flowing into the pockets of senior military officers (both in service and retired) as well as of their relatives and of cronies.

\section{Liberalization as authoritarian resilience}

The Myanmar polity has certainly enjoyed some progress in recent years, but it cannot be defined as a full democracy yet. The current regime has the traits of competitive authoritarianism: electoral results allow for a change in government, but have a limited impact on the military and its substantial political and economic power. Violence and

\section{iris-AperTO}


violation of human rights remain widespread. There are currently more than 600,000 persons who have been internally displaced by the civil war, about $10 \%$ of them in 2017 alone. And in the same year an even larger number of Rohingyas - an ethnic group entirely barred from citizenship - have been forced to leave the country and pushed into Bangladesh (IDMC 2018). The persistence of authoritarian elements of governance in today's Myanmar is not incidental, but, rather, the result of a plan managed by the former incumbents. In order to achieve the intended result, the junta had to keep the process of political transition tightly top-down, crushing, containing or otherwise marginalizing demands from below, from abroad and even from within their ranks. The political transition has not been a democratization but rather a liberalization: a process of political transformation meant to soften authoritarian rule without abandoning it altogether (Dahl 1971; Share and Mainwaring 1986; Huntington 1991; Linz and Stepan 1996).

The very top-down nature of the process of political transformation has been a key element of authoritarian resilience. The availability of the means of repression, combined with shrewd time management in deciding the time and pace of the political reforms, has been essential to defuse pressure for political change. The most noteworthy example can be drawn from the constitutional process. The 1988 uprisings were quelled not only through the use of brutal repression, but also with the promise of a general election, which was held but then transformed into a constitutional election. This led to the institution of the USDA in 1993, which was able to infiltrate social space at the grass-roots level, and to the creation of a constituent assembly, later suspended. In 2003, Khin Nyunt launched the 'Seven step roadmap to democracy', but it was only with the purge that pushed him out of office that the process actually started - that is to say, only after Than Shwe became comfortable with resurrecting the National Convention he himself had introduced and later suspended. The

\section{iris-AperTO}


Saffron Revolution did not manage to change or derail the junta's plan, and it could be argued that the military government learned from its previous experiences, as it contained bloodshed to limit outcry. China, in the role of a 'democratic black knight', provided the junta with reliable economic and political support when no other options were available, granting the incumbents more leeway with their time management.

To date, the liberalization has not, or at least not yet, transformed into a process of democratic transformation, escaping from the hands of its architect and reaching an outcome not originally planned or desired by them (Linz and Stepan 1978; O’Donnell and Schmitter 1986; Huntington 1991; Przeworski 1991). This lack of a full transition to democracy is consistent with the model developed by Levitsky and Way (2010) to account for the stability of hybrid regimes, a definition that can be applied to post-2010 Myanmar as well. The model is based on three elements: 1) the density of cross-border flows and of links between a country and the West; 2) the scope, capacity and cohesion of state and governing structures; and 3) the amount of Western leverage - that is to say, a state's vulnerability to Western pressure in favour of democratization. These elements are checked in sequence. If linkage is high, successful democratization is expected. This was not the case in Myanmar, which after its independence occupied a marginal position for the West both politically and economically. Linkage with China and with ASEAN countries was much stronger. If linkage with the West is low, then the organizational power of the incumbents takes centre stage, and if it is high, then the hybrid regime is able to defy challenges coming from within and from abroad, remaining stable. It is hard to doubt the coercive capacity of the Tatmadaw, as well as its ability to effectively exercise institutional engineering and maintenance. The Tatmadaw is still central to the organization of the state, and it is able to make its voice heard through both formal and informal channels. If organizational power is low, then Western democratizing pressure can 
be effective and work in favour of complete democratization, but this is not the case with Myanmar. This explains why sanctions were not able to bring about a tangible effect (Hufbauer, Schott, and Elliot 2007; Levitsky and Way 2010).

In sum, authoritarian resilience has been the incumbents' ability to use their coercive power and organization, as well as their ability to rely on China, to start a programme of limited political reforms at a time of their choosing, setting its pace according to their own preferences, and bringing it to its intended result but no further. To date, they have been able to keep their ideal end-state steady enough. Perhaps the best proof of persistent authoritarian resilience in Myanmar has been the reaction of the incumbents to the 2015 electoral defeat. Dukalskis and Raymond (2018) argued that the military's lack of knowledge about electoral systems made them pick one that ultimately penalized them. While this may be true, the very fact that the incumbents could but did not turn the tables after the defeat (and even after the creation of the position of State Counsellor) proves that even such shocks do not threaten the system of governance they have devised. This is consistent with Lee Huang's (2017) argument that elections have legitimized and perfected the regime envisioned by the Tatmadaw. The electoral loss also means that the military is no longer perceived as closely related to the messy work of day-to-day governance, leaving it to the NLD and to Aung San Suu Kyi to deal with everyday problems and to pay the price for unpopular choices (Barany 2018: 15-16).

\section{The peculiarities of Myanmar's authoritarian resilience}

What analogies with and differences from other cases of authoritarian resilience already covered in the literature does Myanmar have? Myanmar fits with one of the conclusions reached by Nathan (2003) in his seminal work on China, namely that a ruling social actor not a party, in this case, but the armed forces - can adopt a variety of reforms, both at the 
material and symbolic levels, without triggering a full transition to democracy. Given that Myanmar has become far more liberalized than China, if it manages to maintain its imperfect democracy this would imply that authoritarian resilience can be in play in a broader range of political transitions (not just from authoritarian to authoritarian regimes, but also from authoritarian to hybrid regimes).

Analogies can also be drawn with the case made by Heydemann and Leenders about the Arab Revolts. Certainly, Myanmar's ruling elite was willing "to kill hundreds or thousands of their citizens and injure, arrest, and torture thousands more" (2011: 648), as proved by the 1988 and 2007 repressions, and the "loyalty of the military and security services no doubt mattered, as well, preventing splits among the ruling elite" (2011: 648), as proved by the 2004 purge. But even more importantly, Heydemann and Leenders placed a focus on the regime's "capacity to learn from and adapt to the rapidly emerging challenges that mass uprisings posed for regime survival" (2011: 648). Myanmar's junta was perhaps not very fast in learning and adapting, but its ability to set the pace of political transformation certainly provided options to fix its missteps. The catastrophic 1990 elections were transformed in the 2008 constitution, in which the political power of the Tatmadaw has been enshrined in the most stable way, making it able to survive an electoral defeat (like that of 2015). Heydemann and Leenders also pointed out the advantages of a brief and limited use of violence, in order to contain international reactions. This was definitely not the case in 1988 Myanmar, but it is consistent with what happened in 2007 and with the way in which the junta suppressed the Saffron Revolution without excessive bloodshed.

Further observations can be drawn by setting Myanmar's case in the frame of the model developed by Hess (2013). Myanmar has fared badly in two of four authoritarian vulnerabilities, namely economic performance and corruption. It is an extremely poor 
country: the GDP per capita was only about US\$1,000 a year in 2014 (Gabusi 2015: 54-56), and in 2018 it is still considered a 'least developed country' (LDC), a status held since 1987. As previously recalled, it is beyond doubt that both the 1988 and the 2007 protests were sparked by the catastrophic economic performance of the government and its inability to generate development. Myanmar entered Transparency International's Corruption Perceptions index only in 2005 , at the very bottom of the scale (ranked $155^{\text {th }}$ of 158 countries, ex aequo with Haiti and Turkmenistan), and it is unlikely that the situation was any better before. The country has fared decently regarding inequality and occupation only because of its extreme poverty, and while unemployment rates are officially low the informal economic sector is huge, involving 73\% of the workforce in 2010 (World Bank Group 2014). All in all, substantial authoritarian vulnerabilities have been present in Myanmar, and their impact was probably limited only by the small number of unemployed people.

Authoritarian capacity, however, has been substantial in two of its three dimensions, namely coercive capacity and discretionary control over the economy. Given its track record, the capacity of the Tatmadaw (which also controls the police) to suppress protest and to contain ethnic insurgencies is indisputable. The UMEHL, the MEC and SOEs, along with informal control of commodities in areas in which counter-insurgency operations are conducted, provide the Tatmadaw with massive formal and informal leverage on Myanmar's economy. They also provide economic resources subtracted from social control that are partially used to buy consensus (Gandhi and Przeworski 2006). Only political capacity appears to be poor, if evaluated on the basis of the performances of the NUP and the USDP. But this opinion can perhaps be reversed if the Tatmadaw is considered the real political party, of which the NUP and the USDP are just appendages.

\section{iris-AperTO}


Authoritarian capacity has outmatched authoritarian vulnerability in Myanmar, but in his study Hess argued that repressive capacity may sometimes be overrated due to the opacity of a political system (2013: 263), and this leads to an overestimation of a regime's ability to survive. This in turn explains why the collapse of the regimes in Tunisia and Egypt was so abrupt and unexpected. The opaqueness of Myanmar's political system can hardly be overstated, especially with regard to the years of military rule. For this reason, it makes sense to follow Hess's advice and consider state decentralization, regarded as the mechanism most significant for containing protest at the 'parochial' (i.e., local) level and preventing it reaching the national scale. In this regard, however, Myanmar fares exceptionally poorly. Sub-state units, named either regions or states (under the pretence of major autonomy having been granted to the latter), have very little room for self-government, and as a matter of fact local cabinets are appointed from Naypyidaw. Fiscal and budgetary decentralization is basically non-existent (San San Oo 2016; Shotton, Zin Wint Yee and Khin Pwint Oo 2016) and the level of fiscal extraction per se is one of the lowest in the world, with a tax-to-GDP ratio of less than 5\% (Gabusi 2015: 54-56).

The low level of formal decentralization in Myanmar is striking, and given its negligible scale it could not have produced much authoritarian resilience. Hence, either Hess's analysis does not apply to Myanmar or there is something else that needs to be captured. It could be the divide-and-rule policy followed by the Tatmadaw to keep ethnic armed organizations separated from one another, democratic protestors separated from insurgents, and that generates scapegoats (with Rohingyas being the most obvious example) may very well be the reason for which parochial protests have never managed to merge and to create a truly nationwide contestation. After all, the "centrality of the periphery" in determining the political

\section{iris-AperTO}


trajectory of government in Myanmar is widely acknowledged as fact among country experts (Woods 2011; Meehan 2011 and 2015; Jones 2014; Gabusi 2018).

\section{Conclusions}

Myanmar can appear at first glance as a case of unsuccessful authoritarian resilience: after the failed democratization of 1988-1990, the junta attempted a transformation meant to protect authoritarian governance, but then reform escaped from its grasp as their party (the USDP) lost in the 2015 elections. The analysis of Myanmar's transition provided here challenges such interpretation, and, rather, asserts that the current state of Myanmar's polity is a planned point of arrival. Than Shwe willingly embraced Khin Nyunt's roadmap for reforms (after removing Khin Nyunt) and followed it thoroughly. The Tatmadaw accepted the idea of yielding government to civilians, and to the NLD in particular, as it managed to secure its vital interests while leaving its former opponents to deal with the burden of day-to-day governance. The 2008 constitution managed to formalize the power of the Tatmadaw and, notwithstanding some revision attempts, it has survived intact to date. The military remains the major player in the field of security, with tangible effects on the peace process and on issues of everyday governance in areas of ethnic contestation. It also maintains substantial economic power (along with the ability to distribute rents) thanks to economic conglomerates, SOEs and informal commodity extraction in the borderlands.

The analysis of the events from 1988 onwards has provided an answer to the first question informing this article: is Myanmar's transition a case of democratization or, rather, of authoritarian resilience? As has been shown, it is the latter rather than the former. As the incumbents guided the process of liberalization, they managed to limit and contain democracy. Today, Myanmar is not yet a full democracy, and it remains to be seen whether

\section{iris-AperTO}


and when such a result will be reached. This is consistent with arguments presented by Jones (2014) and Egreteau (2016). The latter specifically stated that "the Tatmadaw leadership, by effectively engaging a transitional opening in the early 2010s, merely opted to move down a notch on the scale of political intervention" and not withdraw completely to the barracks (2016: 129).

A follow-up question that remains open is: will liberalization, at some point, escape from the hands of its architects and managers and push Myanmar further along the road to democracy? Or will they, rather, be able to maintain control and keep the country's regime in a position considered acceptable for them? Egreteau (2016) suggested that the quality of Myanmar's democracy will improve once there is a move away from charismatic leadership and when a new class of leaders emerges. While the potential benefits attached to such developments (which are, unfortunately, not yet happening) are not questioned here, it is possible that they would not be sufficient if the structural factors recalled by Levitsky and Way's (2010) model did not change as well, in particular the organizational power of the Tatmadaw, given the relative marginality of Myanmar for the West. Hybridity is not necessarily synonymous with instability, and in fact it is possible for Myanmar's current regime to last for a while longer. In this respect, the analysis presented here diverges from the more optimistic, incrementalist view proposed by Farrelly (2015).

Granted that Myanmar's democratic progress to date has been a case of authoritarian resilience rather than of democratization, this article is also intended to answer a second question: how has authoritarian resilience worked in Myanmar and what peculiarities has it presented? Three features are of particular interest. First, the very top-down nature of the liberalization and the capacity of the incumbents not to lose their grasp of the process have formed the first and most obvious element of authoritarian resilience. Second, their ability to

\section{iris-AperTO}


set the pace of political transformation has granted the incumbents time to contain and divert demands for change that did not align with their own vision. These results have been achieved not exclusively through repression, but also through other means of political engineering (examples of which include changing a general election into a constitutional one, or infiltrating civil society space). Third, the divide-and-rule strategy employed by the Tatmadaw, both when in power and in the new era of civilian rule, has provided a means of keeping contestations separated and parochial, and hence manageable and not destabilizing.

\section{Funding}

The research received no grants from public, commercial or non-profit funding agency

\section{Data}

The replication dataset is available at http://thedata.harvard.edu/dvn/dv/ipsr-risp

\section{References}

Alamgir, Jalal. 2008. 'Myanmar's foreign trade and its political consequences.' Asian Survey 48(6): 977-996.

ANU Myanmar Research Center. 2015. The Meaning of Myanmar's 2015 elections. Canberra: $\begin{array}{lll}\text { Australian National University. } & \text { Online: }\end{array}$ http://bellschool.anu.edu.au/sites/default/files/uploads/201608/2015_myanmar_report_final_2016_03_30.pdf, accessed 05/06/2018. 
Aung San Suu Kyi. 2018. Democratic Transition in Myanmar: Challenges and the Way Forward. The $43^{\text {rd }}$ Singapore Lecture. 21 August 2018. Singapore: ISEAS-Yusof Ishak Institute. Online: https://www.iseas.edu.sg/images/43rd-Singapore-Lecture-Speech-by-Aung-San-Suu-KyiFinal-transcript.pdf, accessed 30/10/2018.

Barany, Zoltan. 2018. 'Burma: Suu Kyi's Missteps.' Journal of Democracy 29(1): 5-19.

Bellamy, Alexander J., and Catherine Drummond. 2012. 'Southeast Asia: between noninterference and sovereignty as responsibility', in Knight, Andy, and Frazer Egerton, eds. The Routledge Handbook of the Responsibility to Protect. Abingdon and New York: Routledge, 245256.

Bellin, Eva. 2012. 'Reconsidering the Robustness of Authoritarianism in the Middle East: Lessons from the Arab Spring.' Comparative Politics 44(2): 127-149.

Bogaards, Matthijs. 2009. 'How to classify hybrid regimes? Defective democracy and electoral authoritarianism.' Democratization 16(2): 399-423.

Brenner, David. 2015. 'Ashes of co-optation: from armed group fragmentation to the rebuilding of popular insurgency in Myanmar.' Conflict, Security \& Development 15(4): 337358.

Brenner, David. 2017. 'Authority in rebel groups: identity, recognition and the struggle over legitimacy.' Contemporary Politics 23(4): 408-426.

\section{iris-AperTO}


Cassani, Andrea. 2014. 'Hybrid what? Partial consensus and persistent divergences in the analysis of hybrid regimes.' International Political Science Review 35(5): 542-558.

Cassani, Andrea, and Luca Tomini. 2018. 'Reversing regimes and concepts: from democratization to autocratization.' European Political Science. Online first. 4 May 2018.

Chambers, Justine, and Gerard McCarthy. 2018. 'Introduction: Myanmar transformed?', in Chambers, Justine, McCarthy, Gerard, Farrelly, Nicholas and Chit Win, eds. Myanmar Transformed? People, Places, Politics. Singapore: ISEAS-Yusof Ishak Institute, 3-20.

Charney, Michael W. 2009. A history of modern Burma. Cambridge: Cambridge University Press.

Chung, Yousun. 2017. 'Manifestation of Authoritarian Resilience?: Evolution of Property Management in Beijing.' Journal of International and Area Studies 24(1): 85-103.

Cribb, Robert. 1998. 'Burma's entry into ASEAN: Background and Implications.' Asian Perspective 22(3): 49-62.

Crouch, Melissa, and Tom Ginsburg. 2016. 'Between endurance and change in South-East Asia: the military and constitutional reform in Myanmar and Thailand.' Annual Review of Constitution-Building Processes: 2015. Stockholm: Institute for Democracy and Electoral Assistance, 67-81.

Dahl, Robert. 1971. Polyarchy: Participation and opposition. New Haven: Yale University Press.

\section{iris-AperTO}


Diamond, Larry J. 2000. 'Is Pakistan the (reverse) wave of the future?' Journal of Democracy, 11(3): 91-106.

Diamond, Larry J. 2002. 'Thinking about hybrid regimes.' Journal of Democracy 13(2): 21-35.

Dukalskis, Alexander, and Christopher D. Raymond. 2018. 'Failure of authoritarian learning: explaining Burma/Myanmar's electoral system.' Democratization 25(3): 545-563

Egreteau, Renaud. 2016. Caretaking Democratization: The Military and Political Change in Myanmar. London: Hurst.

Farrelly, Nicholas. 2015. 'Beyond electoral authoritarianism in transitional Myanmar.' European Journal of East Asian Studies 14(1): 15-31.

Farrelly, Nicholas. 2018. 'The capital', in Simpson, Adam, Farrelly, Nicholas, and Ian Holliday, eds. Routledge Handbook of Contemporary Myanmar. Abingdon and New York: Routledge, 5563.

Freedom House. 2016. Freedom House Report: Myanmar. Online:

https://freedomhouse.org/report/freedom-world/2016/myanmar, accessed 22/05/2018.

Gabusi, Giuseppe. 2015. 'State, market and social order: Myanmar's Political Economy Challenges.' European Journal of East Asian Studies 14(1): 52-75. 
Gabusi, Giuseppe. 2018. 'Change and continuity: capacity, co-ordination, and natural resources in Myanmar's periphery', in Chambers, Justine, McCarthy, Gerard, Farrelly, Nicholas and Chit Win, eds. Myanmar Transformed? People, Places, Politics. Singapore: ISEAS-Yusof Ishak Institute, 137-160.

Gandhi, Jennifer, and Przeworski, Adam. 2006. 'Cooperation, Cooptation, and Rebellion under Dictatorship.' Economics \& Politics 18(1): 1-26.

Garver, John G. 2011. Protracted Contest: Sino-Indian Rivalry in the Twentieth Century. Oxford and New Delhi: Oxford University Press.

Hess, Steve. 2013. 'From the Arab Spring to the Chinese Winter: The institutional sources of authoritarian vulnerability and resilience in Egypt, Tunisia, and China.' International Political Science Review 34(3): 254-272.

Heydemann, Steven, and Reinoud Leenders. 2011. 'Authoritarian learning and authoritarian resilience: Regime responses to the Arab awakening.' Globalization 8(5): 647-653.

Holliday, Ian. 2010. 'Voting and violence in Myanmar: Nation building for a transition to democracy', in Dittmer, Lowell, ed. Burma or Myanmar? The struggle for national identity. Singapore: World Scientific Publishing.

Htoo Thant. 2016. 'State counsellor bill approved despite military voting boycott.' Myanmar Times. 5 April 2016. Online: https://www.mmtimes.com/national-news/19844-militaryprotests-but-parliament-passes-state-counsellor-bill.html, accessed 30/10/2018.

\section{iris-AperTO}


Hufbauer, Gary Clyde, Schott, Jeffrey J., and Kimberly Ann Elliott. 2007. Economic Sanctions Reconsidered: History and Current Policy. Washington DC: Institute for International Economics.

Huntington, Samuel. 1968. Political Order in Changing Societies. New Haven and London: Yale University Press.

Huntington, Samuel. 1991. The third wave: Democratization in the late twentieth century. Oklahoma City: University of Oklahoma Press.

International Crisis Group (ICG). 2012. 'Myanmar: The Politics of Economic Reform.' Asia Report No. 231 (27 July 2012). Online: http://www.crisisgroup.org/ /media/Files/asia/south-east-asia/burma-myanmar/231myanmar-the-politics-of-economic-reform.pdf, accessed 05/06/2018.

International Crisis Group (ICG). 2015. 'The Myanmar elections: results and implications.' Crisis Group Asia Briefing No. 147. 9 December 2015.

International Displacement Monitoring Centre (IDMC). 2018. Myanmar. Online: http://www.internal-displacement.org/countries/myanmar, accessed 30/10/2018.

Jones, Lee. 2014. 'Explaining Myanmar's regime transition: the periphery is central.' Democratization, 21(5): 780-802. 
Khin Maung Win. 2004. Myanmar Roadmap to Democracy: The Way Forward. Yangon: Myanmar Institute of Strategic and International Studies. Online: http://burmatoday.net/burmatoday2003/2004/02/040218_khinmgwin.htm, accessed 22/05/2018.

Kipgen, Nehginpao. 2016. Democratisation of Myanmar. Abingdon and New York: Routledge.

Kyaw Yin Hlaing. 2013. 'The four-eights democratic movement and political repression in Myanmar', in Naranyan Ganesan, and Chill Kim Sung, eds. State Violence in East Asia. Lexington (KY): University Press of Kentucky.

Lee, John. 2012. 'Is Burma turning on China? How Burma's pivot away from its longtime partner debunks the myth of China's diplomatic prowess.' The National Interest. 1 February 2012. Online: http://nationalinterest.org/commentary/burma-turning-china-6438, accessed $05 / 06 / 2018$.

Lee Huang, Roger. 2017. 'Myanmar's Way to Democracy and the Limits of the 2015 Elections.' Asian Journal of Political Science 25(1): 25-44.

Levitsky, Steven, and Lucan A. Way. 2002. 'The Rise of Competitive Authoritarianism.' Journal of Democracy 13(2): 51-65.

Levitsky, Steven, and Lucan A. Way. 2010. Competitive authoritarianism: The emergence and dynamics of hybrid regimes in the post-Cold War era. Cambridge and New York: Cambridge University Press. 
Levitsky, Steven, and Lucan A. Way. 2015. 'The myth of democratic recession.' Journal of Democracy 26(1): 48-58.

Linz, Juan J., and Alfred Stepan. 1978. The breakdown of democratic regimes. Baltimore: Johns Hopkins University Press.

Linz, Juan J., and Alfred Stepan. 1996. Problems of democratic transition and consolidation: Southern Europe, South America and Post-communist Europe. Baltimore: Johns Hopkins University Press.

Lynch, Marc. 2011. 'After Egypt: The Limits and Promise of Online Challenges to the Authoritarian Arab State.' Perspectives on Politics 9(2): 301-310.

Macdonald, Adam P. 2013. 'From Military Rule to Electoral Authoritarianism: The Reconfiguration of Power in Myanmar and its Future.' Asian Affairs: An American Review 40(1): 20-36.

MacFarquhar, Neil. 2010. 'U.N. doubts fairness of Election in Myanmar.' New York Times. 21 October 2010. Online: https://www.nytimes.com/2010/10/22/world/asia/22nations.html, accessed 22/05/2018.

Maung Aung Myoe. 2018. 'Partnership in politics: the Tatmadaw and the NLD in Myanmar since 2016', in Chambers, Justine, McCarthy, Gerard, Farrelly, Nicholas and Chit Win, eds. Myanmar Transformed? People, Places, Politics. Singapore: ISEAS-Yusof Ishak Institute, 201229.

\section{iris-AperTO}


Meehan, Patrick. 2011. 'Drugs, insurgency and statebuilding in Burma: Why the drugs trade is central to Burma's changing political order.' Journal of Southeast Asian Studies 42(3): 376404.

Meehan, Patrick. 2015. 'Fortifying or fragmenting the state? The political economy of the drug trade in Shan State, Myanmar, 1988-2012.' Critical Asian Studies 47(2): 253-282.

Morgenbesser, Lee. 2015. 'In search of stability.' European Journal of East Asian Studies 14(2): 163-188.

Mya Than. 2005. 'Cooperation with the People's Republic of China and Thailand in the Greater Mekong Subregion.' Journal of GMS Development Studies (2)1: 37-54.

Myanmar Times. 2016. 'Transcript: President U Htin Kyaw's inaugural address.' 30 March 2016. Online: https://www.mmtimes.com/national-news/19730-transcript-president-u-htinkyaw-s-inaugural-address.html, accessed 30/10/2018.

Myat Thein. 2004. Economic Development of Myanmar. Singapore: ISEAS.

Nathan, Andrew J. 2003. 'Authoritarian resilience.' Journal of Democracy 14(1): 6-17.

National League for Democracy (NLD). 2015. 2015 Election Manifesto. Online: http://www.burmalibrary.org/docs21/NLD_2015_Election_Manifesto-en.pdf, accessed $30 / 10 / 2018$. 
O’Donnell, Guillermo, and Philippe C. Schmitter. 1986. Transitions from authoritarian rule: Tentative conclusions about uncertain democracies. Baltimore: Johns Hopkins University Press.

Olarn, Kocha. 2012. 'Myanmar confirms sweeping election victory for Suu Kyi's party.' CNN. 4 April 2012. Online: https://edition.cnn.com/2012/04/04/world/asia/myanmarelections/index.html, accessed 22/05/2018.

President's Office. 2018. The full text of the speech delivered by President $U$ Win Myint at the ceremony to take oath of office at Pyidaungsu Hluttaw. 30 March 2018. Online: http://www.president-office.gov.mm/en/?q=briefing-room/speeches-andremarks/2018/03/31/id-8618, accessed 30/10/2018.

Przeworski, Adam. 1991. Democracy and the Market. Cambridge and New York: Cambridge University Press.

Ramachandran, Sudha. 2012. 'China-South Asia strategic engagements - 3. Sino-Myanmar relationship: past imperfect, future tense.' ISAS Working Paper No. 158. 23 August 2012. Singapore: National University of Singapore.

Ramachandran, Sudha. 2016. 'Chinese influence faces uncertain future in Myanmar.' China Brief (16)4: 10-13.

Rieffel, Lex. 2015. 'Policy options for improving the performance of the state economic enterprise sector in Myanmar.' ISEAS Working Paper No. 1. Singapore: National University of Singapore. 
Ruzza, Stefano. 2015. 'There are two sides to every COIN: Of economic and military means in Myanmar's comprehensive approach to illiberal peacebuilding.' European Journal of East Asian Studies 14(1): 76-97.

Ruzza, Stefano, and Giuseppe Gabusi. 2018. 'Myanmar', in Giessmann, Hans J., and Roger MacGinty, eds. The Elgar Companion on Post-Conflict Transition. Cheltenham: Edward Elgar Publishing, 275-293.

San San Oo. 2016. Fiscal Management Reform in Myanmar. Policy Research Institute, Ministry of Finance, Japan. Online: https://www.mof.go.jp/pri/international_exchange/visiting_scholar_program/fy2016/sansa n2.pdf, accessed 22/05/2018.

Schedler, Andreas. 2002. 'The menu of manipulation.' Journal of Democracy 13(2): 36-50.

Schedler, Andreas. 2006. 'The Logic of Electoral Authoritarianism', in Schedler, Andreas, ed. Electoral Authoritarianism: The Dynamics of Unfree Competition. Boulder: Lynne Rienner Publishers.

Share, Don, and Scott Mainwaring. 1986. 'Transitions Through Transaction: Democratization in Brazil and Spain', in Selcher, Wayne A., ed. Political Liberalization in Brazil: Dynamics, Dilemmas, and Future Prospects. Boulder: Westview Press.

Shotton, Roger, Zin Wint Yee and Khin Pwint Oo. 2016. State and Region Financing, Planning and Budgeting in Myanmar. What are the Procedures and What are the Outcomes? Yangon:

\section{iris-AperTO}


Renaissance Institute and The Asia Foundation. Online: http://www.burmalibrary.org/docs23/AF-2017-02-08-State-and-Region-FinancingBudgeting-and-Planning-in-Myanmar-en-tpo-red.pdf, accessed 22/05/2018.

South, Ashley. 2008. Ethnic politics in Burma: States of conflict. London and New York: Routledge.

Steinberg, David I., and Hongwei Fan. 2012. Modern China-Myanmar Relations: Dilemmas of Mutual Dependence. Copenhagen: NIAS Press.

Stockmann, Daniela, and Mary E Gallagher. 2011. 'Remote Control: How the Media Sustain Authoritarian Rule in China.' Comparative Political Studies 44(4): 436-467.

Transparency International. 2018. Corruption Perceptions Index. Online: https://www.transparency.org/research/cpi/overview, accessed: 22/05/2018.

Way, Lucan A. 2004. 'The sources and dynamics of competitive authoritarianism in Ukraine.' Journal of Communist Studies and Transition Politics 20(1): 143-161.

Way, Lucan A. 2008. 'The real causes of the color revolutions.' Journal of Democracy 19(3): 55-69.

Whitehead, Laurence. 2016. 'The "puzzle" of autocratic resilience/regime collapse: the case of Cuba.' Third World Quarterly 37 (9): 1666-1682. 
Wigell, Mikael. 2008. 'Mapping Hybrid Regimes: Regime Types and Concepts in Comparative Politics.' Democratization 15(2): 230-250.

Woods, Kevin. 2011. 'Ceasefire capitalism: military-private partnerships, resource concessions and military-state building in the Burma-China borderlands.' Journal of Peasant Studies 38(4): 747-70.

World Bank Group. 2014. Myanmar: ending poverty and boosting shared prosperity in a time of transition. November 2014. Yangon: World Bank Group. Online: http://www.worldbank.org/content/dam/Worldbank/document/EAP/Myanmar/WBG_SCD_ Full_Report_English.pdf, accessed 22/05/2018.

Yom, Sean L., and Gregory F. Gause. 2012. 'Resilient Royals: How Arab Monarchies Hang On.' The Journal of Democracy 23(4): 74-88.

Zaw Oo and Win Min. 2007. Assessing Burma's Ceasefire Accords. Washington DC: East-West Center. 


\section{Figures and tables}

Myanmar - Democracy indices, 1988-2017

1

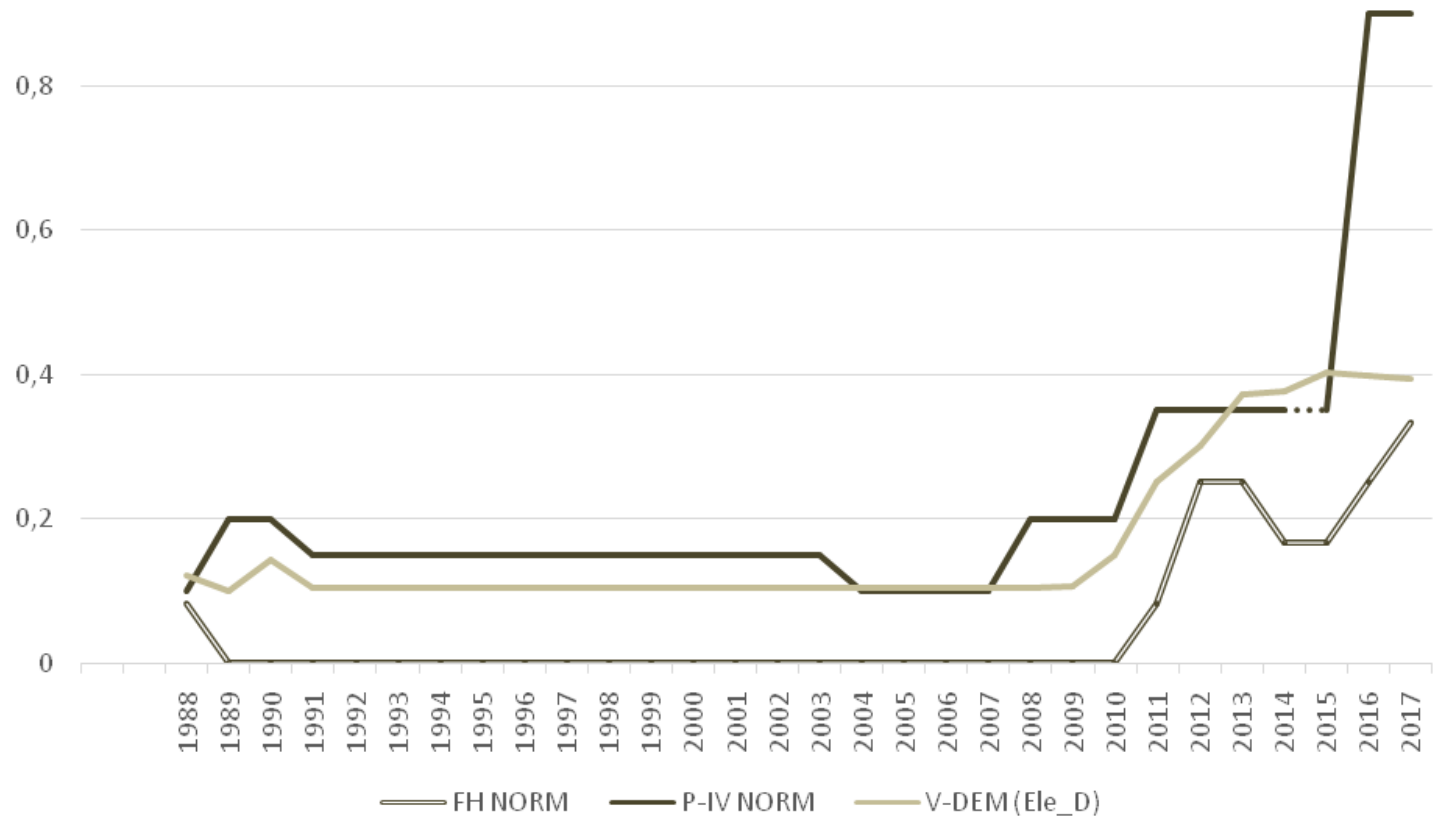

Figure 1

Note: All indices have been normalized to a $0-1$ range (the one used by the V-Dem index) to allow for comparison. Appendix 1 reports the values of the indices on their original scales.

Source: Authors' own elaboration of data from Freedom House (Freedom rating), Center for Systemic Peace (Polity IV), and Varieties of Democracy (V-Dem). 


\begin{tabular}{|c|c|c|c|}
\hline Year & FH & P-IV & $\begin{array}{l}\text { V-DEM } \\
\text { (Ele_D) }\end{array}$ \\
\hline 1988 & 6.5 & -8 & 0.11 \\
\hline 1989 & 7 & -6 & 0.10 \\
\hline 1990 & 7 & -6 & 0.13 \\
\hline $1991 \|$ & 7 & -7 & 0.10 \\
\hline 1992 & 7 & -7 & 0.10 \\
\hline 1993 & 7 & -7 & 0.10 \\
\hline 1994 & 7 & -7 & 0.10 \\
\hline 1995 & 7 & -7 & 0.10 \\
\hline 1996 & 7 & -7 & 0.10 \\
\hline 1997 & 7 & -7 & 0.10 \\
\hline 1998 & 7 & -7 & 0.10 \\
\hline 1999 & 7 & -7 & 0.10 \\
\hline 2000 & 7 & -7 & 0.10 \\
\hline 2001 & 7 & -7 & 0.10 \\
\hline 2002 & 7 & -7 & 0.10 \\
\hline 2003 & 7 & -7 & 0.10 \\
\hline 2004 & 7 & -8 & 0.10 \\
\hline 2005 & 7 & -8 & 0.10 \\
\hline 2006 & 7 & -8 & 0.10 \\
\hline 2007 & 7 & -8 & 0.10 \\
\hline 2008 & 7 & -6 & 0.10 \\
\hline 2009 & 7 & -6 & 0.10 \\
\hline 2010 & 7 & -6 & 0.12 \\
\hline 2011 & 6.5 & -3 & 0.22 \\
\hline 2012 & 5.5 & -3 & 0.29 \\
\hline 2013 & 5.5 & -3 & 0.35 \\
\hline 2014 & 6 & -3 & 0.36 \\
\hline 2015 & 6 & -88 & 0.37 \\
\hline 2016 & 5.5 & 8 & 0.40 \\
\hline 2017 & 5 & 8 & 0.39 \\
\hline
\end{tabular}

FH: Freedom House (Freedom Rating) P-IV: Polity IV Index

V-Dem (Ele_D): V-Dem, Electoral

Democracy Index

Table 1: Myanmar - Democracy indices, 1988-2017 